\title{
Current Issues of Application of Hague Child Protection Convention of 1996 on National Level
}

\author{
Aslan Khuseinovich Abashidze ${ }^{1}$
}

Alexandr Mikhailovich Solntsev²

Alexandra Evgenyevna Koneva ${ }^{3}$

Denis Andreevich Gugunskiy ${ }^{4}$

Natalya Anatolyevna Grigorieva ${ }^{5}$

\begin{abstract}
1 Department of International Law, Peoples' Friendship University of Russia, Moscow, Russian Federation
2 Department of International Law, Peoples' Friendship University of Russia, Moscow, Russian Federation

${ }^{3}$ Department of International Law, Peoples' Friendship University of Russia, Moscow, Russian Federation

${ }^{4}$ Department of International Law, Peoples' Friendship University of Russia, Moscow, Russian Federation

${ }^{5}$ Department of History of Russia, Peoples' Friendship University of Russia, Moscow, Russian Federation
\end{abstract}

\section{Doi:10.5901/mjss.2015.v6n4s4p289}

\section{Abstract}

In 2013 the Russian Federation has become a State party to Convention on Jurisdiction, Applicable Law, Recognition, Enforcement and Co-operation in respect of Parental Responsibility and Measures for the Protection of Children's Rights of October 19, 1996 (Hague Child Protection Convention of 1996). At this moment given the social importance of the Convention there is a pressing need for its effective application in the territory of the Russian Federation. For this purpose it is necessary to develop comprehensive guidelines on the procedures for applying the provisions of the Convention by the Russian authorities at all levels. Due to the fact that the experience of implementing the 1996 Hague Convention in the Russian Federation is not so extensive, it is especially important to study the practice of application of the Convention in another Member States, particularly Germany, Great Britain and Finland, in order to reveal the most effective ways of its implementation. The authors of the article analyse substantial provisions of the Convention, examine the existing procedures for the practical operation of the Convention in the Russian Federation and difficulties in this relation, give an overview of the first case of its application in the Russian legal proceedings, provide analysis of the realisation of Convention in the indicated States and determines the areas where this experience may be valuable for the Russian Federation.

Keywords: international law, human rights, children's rights, parental responsibility, measures for the protection of children, Hague conference, Hague Child Protection Convention of 1996

\section{Introduction}

Today Russia is facing an acute problem of protecting the rights of children. The Russian Federation is taking significant efforts to reach this goal. Protecting children's rights is one of the top priorities of Russia's domestic and foreign policy. In recent years, legislative and institutional reforms were initiated, the post of Ombudsman for the protection of children's rights was established and the National Strategy of Action for the benefit of Children for the period of 2012-2017 was adopted (Presidential Decree No. 761 of June 1, 2012 on the National Strategy of Action for Children for 2012-2017) (Note 1). Meanwhile, the measures undertaken by the State to support the children are largely stipulated by the international obligations assumed by Russia as a result of joining international treaties related to the protection of children's rights.

One of the most challenging human rights issues is to ensure that the rights of children to communicate with their parents are duly respected, especially in cases when parents are living separately and, as it happens quite often, in different countries (Bosisio, 2012). Problems arising between parents often result in restricted access of one of the parents to a child, child abduction, the non-return of the child to the other parent, etc. Problems of this nature are regulated by the Hague Convention on the Civil Aspects of International Child Abduction, October 25, 1980 (hereinafter the 1980 Convention). Participation to the Convention allows to provide certain guarantees of the rights of children and 
their parents (or other legal representatives) at the international level in order to create a legal mechanism of interaction between states in deciding on the return of children wrongfully removed to or retained in other states (Vigers, 2011).

The Russian Federation acceded to the above Convention on the basis of the Federal Law of 31 May 2011 (Federal law as of 31.05.2011 No. 102-FZ "On the accession of the Russian Federation to the Hague Convention on the Civil Aspects of International Child Abduction"). After three years since the entry into force of the 1980 Convention the Federal Act No. 126-FZ on amendments in legislation of the Russian Federation in connection with the accession to the 1980 Convention was adopted (Federal law as of 5 May 2014 No. 126-FZ "On amendments to some legislative acts of the Russian Federation in connection with the accession of the Russian Federation to the Hague Convention on the Civil Aspects of International Child Abduction Child Abduction"). The afore-referred Act amended the following four laws: the Law of the Russian Federation "On Private Detective and Security Activity in the Russian Federation"; Family Code of the Russian Federation; The Federal Law On Bailiffs; Code of Civil Procedure of the Russian Federation; Federal Law "On Enforcement Proceedings."

The Convention "On Jurisdiction, Applicable Law, Recognition, Enforcement and Co-operation in respect of Parental Responsibility and Measures for the Protection of Children's Rights" of October 19, 1996 (hereinafter - the 1996 Convention) is another international legal instrument regulating some of the above-mentioned problems. This convention became effective in the Russian Federation on June 1, 2013. However, the practice of the application of this international treaty in the territory of Russia is not so extensive. The reason for this lies in the fact that the provisions of the 1996 Convention are little known by the competent authorities and population (Pardeck, 2006). Taking this into account and the social importance of the 1996 Convention, there is a pressing need for its effective application in the territory of the Russian Federation. For this purpose it is necessary to develop comprehensive guidelines on the procedures for applying the provisions of the 1996 Convention by the Russian authorities at all levels. Therefore, there is a need in a comprehensive analysis of the substantial provisions of the Convention, determination of difficulties of its implementation in the Russian Federation and other States Parties as well as experience of the realisation of the Convention in these States Parties which could be useful for Russia.

\section{Literature Review}

The issues of the implementation of international acts in the sphere of protection of children's rights in situations when their parents are living in different States are studied by various experts in Russia as well as in other countries (Solntsev \& Koneva, 2013). In this relation vast research has been conducted on the issue of application of the 1980 Convention in the territory of the Russian Federation, on the compatibility of the Russian legislation with the provisions of this Convention (Abashidze et al., 2015; Khazova, 2012; Trigubovich, 2014; Kabanov, 2014; Schepetkova, 2014). Certain publications are devoted to the question of potential ratification and application of the European Convention on the exercise of children's rights of 1996 (adopted within Council of Europe) in Russian Federation (Sheljutto, 2014).

Meanwhile, the 1996 Convention has not been the subject of a comprehensive study in academic area and there are comparatively smaller number of publications devoted to this international treaty and its practical operation in the territory of contracting States, including Russia (Khazova et al., 2013).

\section{Method}

The article applied scientific methodological approach which allows to determine the scope of the study, clarify the basic concepts and categories and highlight the key conceptual aspects of the research topic. The study used scientific methods of cognition, such as dialectics, analysis and synthesis, the method of generalization, system-structural method. The authors also widely used special methods of science: legal and technical, historical, method of forecasting.

The task of a comprehensive analysis of the research topic has necessitated the use of the comparative method of research in relation to implementation processes in various States, which was dictated by the need for a scientific understanding of the issues and trends in the realisation of the 1996 Convention.

The authors of the article analyse substantial provisions of the Convention, examine the existing procedures for the practical operation of the Convention in the Russian Federation and difficulties in this relation, give an overview of the first case of its application in the Russian legal proceedings, provide analysis of the realisation of Convention in the indicated States and determines the areas where this experience may be valuable for the Russian Federation. 


\section{Results and Discussion}

The 1996 Hague Convention was adopted to protect the interests of different groups of children in a variety of cases.

It is worth emphasizing that the 1996 Hague Convention is not intended to replace the UN Convention on the Rights of the Child of 1989 (Jones and Walker, 2011). The main objective of the 1996 Hague Convention is the resolution of legal and administrative conflicts between national legal systems in respect of measures to protect children and to provide a framework for effective international cooperation in this area. According to Art. 50 of the 1996 Hague Convention, this Convention shall not affect the application of the 1980 Hague Convention by the States Parties to both Conventions. However, this provision does not preclude the application of the 1996 Hague Convention to "either return the child, wrongfully removed or retained, or to exercise the rights of access."

Upon accession to the 1996 Hague Convention, Russia made the following reservations and declarations:

1) In accordance with para. 2 of Art. 54 and para. 1 of Art. 60 of the Convention, the Russian Federation objects to the use of the French language;

2) In accordance with para. 1 of Art. 55 and para. 1 of Art. 60 of the Convention, the Russian Federation recognizes the exclusive jurisdiction of its bodies with respect to actions aimed at protection of the property of the child residing in the territory of the Russian Federation, and reserves the right not to recognize parental responsibility or any measure if it is incompatible with any measure taken by the Russian Federation in respect of the said property;

3) Under the terms of para. 2 of Art. 34 of the Convention the Russian Federation declares that the requests referred to in para. 1 of Art. 34 of the Convention shall only be transmitted through the designated Central Authority.

The 1996 Hague Convention establishes a fundamental principle: judicial or administrative authorities of the State Party to the 1996 Hague Convention must first and foremost have the jurisdiction over measures ensuring the protection of the human person or property of the child in the place of his or her habitual residence. In case of changing the place of habitual residence of the child and his or her emigration to another country, which is a State Party to the 1996 Hague Convention, public authorities of the new place of child's habitual residence will have jurisdiction.

As is the case of the 1980 Hague Convention, under the Convention of 1996, the Ministry of Education and Science of the Russian Federation performs the functions of the Central Authority.

The 1996 Hague Convention applies to children under the age of 18, while the 1980 Convention applies to a child under 16 years.

By analogy with the 1980 Convention, the 1996 Hague Convention shall only apply to measures if they are taken in a State where the Convention has entered into force.

Central Authorities and other public bodies of the State Parties to the 1996 Hague Convention and the 1980 Convention shall bear their own costs in carrying out international cooperation; however, a possibility to set a reasonable fee still remains.

All the documents sent to or received in accordance with the 1980 Convention and the 1996 Hague Convention, shall be exempt from legalization or any similar formality.

As far as the 1996 Convention is concerned, the measures taken by one State Party and which may be recognized and enforced in the territory of another State Party to the Convention of 1996, may be taken by either the courts or administrative bodies.

While the Russian legislation has an appropriate regulation in terms of recognition and enforcement of measures taken by foreign judicial authorities (Article 409 of the Code of Civil Procedure), there is no such regulation in terms of measures taken by the administrative authorities. As to the requests for recognition and enforcement of such measures, civil law norms will apparently have to be applied in a similar way.

On September 11, 2013, for the first time in the history of the Russian judicial practice, a court decision was made on the recognition of a foreign judgment concerning family relationships and the return of children to one of the parents under the 1996 Convention. The Moscow City Court ordered llya Neustadt, a Russian husband of the US citizen Rachel Neustadt to return children whom he had removed to Russia, to their mother.

The background facts are as follows. The Neustadts have three sons: Daniel Jacob, born in March 2006; Jonathan, born in May 2008; and Meir, born in December 2011. R.E. Neustadt and I.V. Neustadt met at the wedding of mutual friends and shortly thereafter got engaged, and in December 2004 legally wedded. The couple lived in Vienna for a while, where I.V. Neustadt studied, but soon moved to Zurich, where their two sons Daniel Jacob and Jonathan were born, and after that the couple moved to London, where they lived together for several years. Here, another child named Meir was born. 
I. V. Neustadt was inattentive and rude to his wife. In 2007 , he began to use violence to his wife, and as a result, their marriage broke up.

The first procedural steps were taken in March 2011, on the initiative of Mrs. Neustadt, who stopped conjugal life with her husband. At that time, she was already pregnant with their third child named Meir. Custody of the children by the court's decision was given to the mother.

Since during the first months of the couple's life in London Mr. Neustadt became increasingly aggressive towards his children, it was decided that the father could only visit his children in the presence of their mother.

In September 2011, Mr. Neustadt agreed to visit a psychiatrist because of his repeated outbursts of rage and to fulfill anger management program. In response to these steps he managed to extra judicially obtain Mrs. Neustadt's permission to enjoy unlimited communication with the children during the day.

In February 2012, the court registered a petition for divorce, but Mrs. Neustadt failed to promptly finalize the process, as Mr. Neustadt deliberately caused delays, refusing to sign the necessary papers.

Later Mr. Neustadt appealed to a London Court, asking to allow him to see the children more days during the week, and to allow him to have unsupervised access to the children at nighttime.

Shortly after, he received Russian passports for two older children in the Russian consulate in London. He persuaded his ex-wife to allow him to take the kids to Moscow for winter holidays to visit his brother P. Neishtadt. Mr. Neishtadt's parents who live in Germany were to take part in the journey.

On January 7,2013 , the day when the children, according to a written agreement between the parents, were to return to London, Mrs. Neustadt received an e-mail from her ex-husband, in which he informed her that the children would not return to England. Over the next month, Mr. Neustadt refused to tell his ex-wife the whereabouts of the children.

Eventually, American lawyers filed a lawsuit in the Moscow City Court, demanding recognition and enforcement of foreign court decision. In their petition, they referred to the 1996 Hague Convention, which had entered into force in Russia on June 1, 2013.

On September 11, 2013, the Moscow City Court ordered to enforce the decision of the Supreme Court of England and Wales in the territory of the Russian Federation, and thus, oblige the father to return children to the mother.

The last appeal hearing at the Moscow City Court on a decision taken on September 11, 2013 took place on November 20,2013. The Court ruled that the children should be transferred to the mother and be returned to England immediately.

Thus, the case of R. Neustadt became the first case of application of the 1996 Convention in the Russian judicial proceedings.

Both Conventions of 1980 and 1996 provide for the duties of the Central Authority for the amicable settlement of conflicts and Federal State Budgetary Institution "Federal Institute of Mediation" (hereinafter - the Institute), set up in 2013, is of great help to the Ministry of Education of Russia in this regard. One of its tasks is to facilitate the Central Authority of the Russian Federation regarding setting up and ensuring mediation procedures with the purpose of resolving family disputes between citizens bringing up children, if they appeal to the Russian Ministry of Education and Science and with the consent of the parties. The Institute is the first and the only public organization in the country in the field of mediation and alternative dispute resolution. The activities of the Institute aim at providing high quality mediation services in resolution of both domestic and international disputes.

Mediators of the Institute conduct their professional activities in accordance with the fundamental principles of mediation established by:

- the Federal Law of the Russian Federation No. 193-FZ of July 27, 2010 "On the Alternative Dispute Resolution Procedure Involving Mediation (based on mediation procedure)" effective in the Russian Federation since January 1 , 2011;

- Code of Mediators of Russia;

- Practice guidelines on the application of the Hague Convention of October 25, 1980 on the Civil Aspects of International Child Abduction.

Applications for mediation services on family disputes resolution, submitted to the Central Authority to be considered under the terms of the 1996 Hague Convention as well as of the 1980 Convention, are dealt by the Institute's professional mediators in Russian and English on a pro-bono basis.

At this moment given the social importance of the 1996 Hague Convention there is a pressing need for its effective application in the territory of the Russian Federation. For this purpose it is necessary to develop comprehensive guidelines on the procedures for applying the provisions of the 1996 Hague Convention by the Russian authorities at all levels. 
Due to the fact that the experience of implementing the 1996 Hague Convention in the Russian Federation in comparison with the 1980 Hague Convention is not so extensive, it is especially important to study the practice of application of the Convention in another Member States in order to reveal the most effective ways of its implementation (Special Commission on the practical operation of the 1980 and 1996 Hague Conventions (1-10 June 2011). Conclusions and Recommendations. Retrieved from http://www.hcch.net/upload/concl28sc6_e.pdf).

To achieve this goal, we will subsequently analyze the enforcement practice in three European countries: Germany, Finland and the UK.

Since the States under this study are members of the EU and cooperation on judicial matters is within the competence of the EU, accession to the 1996 Hague Convention was stipulated by the adoption of the two acts of the EU: Council Decision 2003/93 / EC of 19 December 2003 which authorizes a number of states to sign the 1996 Hague Convention in the interests of the Community, and Council Decision 2008/431 / EC of 5 June 2008 which authorizes a number of Member States to ratify or accede to the Convention of 1996 in the interests of the European Community.

The 1996 Hague Convention came into effect in Germany just four years ago, and its implementation practice record is yet not very extensive. In spite of the fact that the practice of application of the 1996 Hague Convention in Germany is insignificant, a considerable contribution of Germany in the development of international cooperation in the field of international protection of children should be noted.

Federal Republic of Germany signed the 1996 Hague Convention on April 1, 2003 and ratified it on October, 2010. The Convention entered into force in Germany on January 1, 2011.

Upon ratification, Germany made a number of reservations to Art. 23 (recognition of measures taken by the authorities of one Contracting State in all other Contracting States), Art. 26 (enforcement of measures taken in one Contracting State and enforceable there, in another Contracting State), as well as to Art. 52 and Art. 54 of the Hague Convention of 1996.

Germany stated that Art. 23, 26 and 52 of the Hague Convention allow Contracting States to use with flexibility the regime of the Convention on the Recognition and Enforcement of Judgments. EU rules establish a system of recognition and enforcement, which is as flexible as the regime established by the Hague Convention of 1996. Accordingly, the decision made by a court of a EU Member State on matters relating to the scope of the 1996 Hague Convention should be recognized and enforced in Germany by virtue of the application of the relevant EU rules effective in the European Union.

EU internal rules refer to the provisions of Council Regulation EC No. 2201/2003 "On Jurisdiction and recognition and enforcement of judgments in matrimonial matters and the matters of parental responsibility in respect of common children of the spouses" (hereinafter - Regulation "Brussels II") (with subsequent changes). Regulation generally replaced the Conventions between EU Member States that had existed prior to its adoption and are relating to the same subject of regulation. The relations between Finland and Sweden with Denmark, Iceland and Norway regarding the continued application of the Northern Convention on the matrimonial matters of February 6, 1931 between them (Art. 59 para. "a", part 2, of the Regulation) is an exception to the above. When applied between the EU Member States, the Regulation has priority with respect to the following international treaties: the Hague Convention of 5 October 1961 Concerning the Powers of Authorities and the Law Applicable in Respect of the Protection of Minors; The Luxembourg Convention of 8 September 1967 on the Recognition of decisions Relating to the Validity of Marriages; the Hague Convention of 1 June 1970 on the Recognition of Divorces and Legal Separations; European Convention of 20 May 1980 on Recognition and Enforcement of Decisions concerning Custody of Children and on Restoration of Custody of children; the Convention of 1980 (Art. 60 of the Council Regulation).

With regard to the Hague Convention of 1996, Art. 61 of the Council Regulation provides that it is applied in two cases: a) where the child has his/her habitual residence in the territory of a Member State; b) with regard to the recognition and execution of a judgment of a court of a Member State in the territory of another Member State - even if the child has his/her habitual residence in the territory of a third State, if the latter is involved in the Convention.

As a result of the entry into force of the Hague 1996 Convention, the Federal Republic of Germany will carry out necessary changes in its legislation and judicial practice.

At the moment, in order to implement the provisions of the Hague 1996 Convention the German Federal legislative body adopted only one law - the Family Courts Act of 26 January 2005 (International Family Law Procedure Act in the version of the promulgation of 26 January 2005. Federal Law Gazette [Bundesgesetzblatt] part I, 162), which entered into force in September 2009. It is noteworthy that this law was adopted in order to implement several international instruments: EC Council Regulation No. 2201/2003 "On Jurisdiction and recognition and enforcement of judgments in matrimonial matters and the matters of parental responsibility in respect of common children of the spouses" (Regulation "Brussels II"), the Hague Conventions of 1996 and 1980 and the Luxembourg Convention of 1980 on the Recognition and 
Enforcement of Foreign Judgments concerning Custody of Children and on Restoration of Custody of Children.

The law specifies the Federal Office of Justice of Germany as the Central Authority, appointed in accordance with these instruments. Family Courts Act regulates the activity of the German Central Authority (such as matters related to the written translations of incoming and outgoing messages, locating the whereabouts of the child etc). This Act also establishes rules for determining jurisdiction of the judiciary bodies, determines the scope of their competence and regulates the procedural aspects of judicial activities of these institutions.

In accordance with Art. 33 of the 1996 Hague Convention, Germany has also appointed bodies to which requests should be addressed in accordance with Art. 8, 9 and 33 of the Convention. Thus, in accordance with Art. 33 of the Hague Convention the competent bodies authorized to consider the possibility of placing the child in a foster family are either the youth affairs authorities in those Federal Lands of Germany, in the territory of which the placement of the child will take place, or local authorities in those areas, with which, by definition of the Central Authority the child has a substantial connection.

As for the authorities designated for the receipt and consideration of requests according to Art. 8 and 9 of the Convention, their functions in Germany are performed by either German Family Courts, namely the courts on matrimonial matters, or the courts that have jurisdiction in the place of habitual residence of the child, or the courts with jurisdiction in the territory, where it is necessary to ensure the child's care and protection.

In court proceedings, arising in relation to the right to access, parental responsibility or child abandonments, the request may be submitted to the Family Court at the location of the Supreme Court of the Federal Land of habitual residence of the child, if the habitual residence of one of the parents is in another EU Member State or another State Party to the Hague Convention. In this case, the above mentioned courts are designated as family courts of special responsibility.

Germany's Central Authority can assist in determining the court which is competent to receive a request or send a request directly to the relevant court.

German Government notes the difficulties arousing in establishing contacts with other Central Authorities of the States Parties to the 1996 Hague Convention. This is due to the fact that some States Parties have not yet designated such Authorities, while others have provided information on the designated Authorities, without giving any contact information or indicating only the mailing address of such Authorities. This can create serious problems in establishing contacts in extreme situations, in particular those relating to the protection of children (Responses of Germany to the Questionnaire concerning the practical operation of the Hague Convention of 25 October 1980 on the Civil Aspects of International Child Abduction and the Hague Convention of 19 October 1996 on Jurisdiction. Applicable Law, Recognition, Enforcement and Co-Operation in Respect of Parental Responsibility and Measures for the Protection of Children. Prel. Doc. No 1. 27 November 2010. Retrieved from http://www.hcch.net/index_en.php?act=publications.details \&pid=5291\&dtid=33).

Germany's Central Authority has developed and translated template forms of requests and applications relative to the 1980 Hague Convention into many languages and placed them on its official website, which greatly simplifies the task of the Central Authorities of other Convention State Members. However, according to the Central Authority of Germany, the introduction of the common formats of applications and requests in accordance with Art. 8 and 9 of the 1996 Hague Convention, as well as of the certificates issued by the Central Authorities in accordance with Art. 40 of this Convention, may have a positive effect.

At a meeting of the Special Commission on the practical application of the Hague Conventions of 1980 and 1996, it was noted that some countries had already made attempts to establish Contact centers in accordance with the principles of mediation structures functionning. The Special Commission urged Member States to consider the possibility of establishing such Contact centers or to appoint special bodies that would perform these functions. In 2011, Germany began to apply these principles, along with France, Australia, Slovakia, Pakistan and the United States, and established a Contact center for international family mediation - VIII-th Department of the Association of German Nation-wide Public and Private Well-Being affiliated with the German branch of International Social Service.

Germany pays great attention to the international cooperation in the field of international child protection and takes an active part in all sorts of trainings, seminars, conferences and other activities aimed at strengthening the effectiveness of the Hague Convention of 1996. Such activities include, in particular, trainings for judges, Central Authorities staff and legislators, held in The Hague in 2009 and in Ukraine in 2010. The German Foundation for International Legal Cooperation also organized training courses in Ukraine in 2009, which strengthened cooperation between Germany and Ukraine. In addition, within the framework of two national conferences organized in 2009 by the German Central Authority for the Hague network of judges, which includes judges with jurisdiction to consider cases related to the application of the Hague Conventions of 1980 and 1996, the judges themselves presented draft principles on direct communication 
between judicial authorities, which they apply and inform the Hague Conference of their practice.

An analysis of Finland's experience in the application of legal provisions of the Hague 1996 Convention shows that Russia should use the experience of Finland in the field of elaboration of measures to support families in a difficult situation. That applies to both the regulatory framework and the availability of human resources needed for its implementation.

Finland signed the 1996 Hague Convention on April 1, 2003, and ratified it on November 19, 2010. The Convention entered into force in Finland on March 1, 2011.

Upon its accession to the 1996 Hague Convention, Finland made the following statement: Art. 23, 26 and 52 of the Convention allow Contracting States to be flexible in order to recognize and enforce the courts' decisions in a simple and fast way. Community rules have established a system of recognition and enforcement of judgments, which is, at least, not less favorable than the rules laid down by the Hague Convention of 1996. Accordingly, any decision made by a court in a Contracting State of the EU, with respect to matters regulated by the Convention of 1996, will be recognized and enforced in Finland by applying the relevant internal rules of the EU law.

As it was noted in the comments to the Regulations "Brussels II", Finnish courts will consider family cases, even if neither spouse has a place of habitual residence in Finland; in cases when the courts of the State of habitual residence of one of the spouses does not have jurisdiction or if the appeal to the courts of the State of habitual residence is associated with unexplained difficulties; and when in the circumstances of a particular case Finnish court deems appropriate to assume jurisdiction.

The application of the EU law, as well as of the European Convention on the recognition and Enforcement of Decisions concerning Custody of Children and on Restoration of Custody of Children of 20 May 1980, and the Nordic Convention on the Recognition and the Enforcement of Judgments in Civil Matters of 1977 on these issues is specifically highlighted, in a brochure on international child abduction, prepared jointly by the Ministry of Justice and Ministry of Foreign Affairs of Finland, the Ministry of social Affairs and Health, with the participation of the Association for the protection of the rights of abducted children.

Practical application of the Hague Convention of 1996 has not been currently summarized or recapitulated by anyone, including the authorities, the non-governmental organizations or academia. Existing publications emphasize primarily the practical importance the 1980 Hague Convention.

It should be said that the Ministry of Justice acts as the Central Authority of Finland in the context of the Hague Convention of 1996 (Official web-page of Ministry of Foreign Affairs, Ministry of Justice, Ministry of Social Affairs and Health, Association for Abducted Children of Finland "International Child Abduction. Custody of Children. Recognition and enforcement of decisions on custody". Retrieved from http://oikeusministerio.fi/en/index/publications/esitteet/ kansainval inenlapsikaappaus/alkusanat.html).

Court decisions relating to the application of the Hague Convention of 1996 are only passed by a single judicial authority, namely - the Court of Appeal of Helsinki.

The law on Child Custody and Right of Access (Act No. 361/1983, as amended - No. 186/1994) was enacted in Finland in 1983. Since this Act affects many of the provisions of the Hague Convention of 1996, we deem it advisable to set out the relevant provisions of the above-mentioned Act as Annex IV to the present Research Opinion, especially as there is no translation of the text of the Act into Russian.

As far as the recognition of foreign judgments in Finland is concerned, the actual practice runs as follows:

- If the issue under consideration concerns the right of access and the protection of children, and the judgment was made in one of the Nordic countries (Sweden, Norway, Denmark), it is enforced directly by the District Court of the place of residence of the child;

- If the decision is rendered by the court of a non-Nordic country, the District Court or the Court of Appeal of Helsinki, upon request, confirms the possibility of enforcement of the judgment in Finland.

In general, foreign courts' decisions are usually positively perceived and enforced in Finland. However, in case of an apparent inconsistency of the foreign judgment regarding the best interests of the child or unacceptable procedural irregularities, enforcement of such decision may be refused with a reference to the relevant provisions of the 1980 Hague Convention.

Specific procedural rules on recovery cases and appeals against decisions under the 1980 Convention have some particularities: decisions on such cases must be brought within six weeks, and this rule is usually observed.

Finland's official response to the Standing Bureau of the Hague Conference on Private International Law indicates the absence of the practice of direct communication between Finish judges/enforcers with colleagues of the requesting States when considering the return of children under the 1980 Hague Convention.

In response, the Government of Finland notes that special difficulties arise when a criminal case is opened against 
a parent of the retained child. Such cases require a close and urgent collaboration between the relevant authorities of the two States. In the event of a criminal investigation into child abduction in the territory of Finland, Central Authority, i.e. the Ministry of Justice, may, upon request of the parent of the retained child, contact the police of the requesting State to organize the participation of this parent in the legal procedures relative to child protection.

To implement the provisions of the Hague Convention of 1996, a special law (No. 435/2009) was passed in Finland and a number of legal acts were amended, such as the Act of Child Protection and the Right to Access of 1983 and the like-named decree of 1994.

Dissemination of information on the Hague Convention of 1996, on approval of the official authorities of Finland, is carried out through the website of the Ministry of Justice, and on national scale - through the municipal Ministries of Social Affairs and Health. But in fact, publicly available information only concerns the matters relative to the child abduction and the relevant Convention of 1980, whereas the Hague Convention of 1996 does not appear there.

An analysis of Great Britain's experience in the application of the norms of the Convention of 1996 shows the following. Russia should use the UK experience in the field of scrutinous elaboration of the legislations of its territorial entities (Northern Ireland, Wales and Scotland).

In 2001, the United Kingdom held a public debate on the signing and ratification of the Hague Convention of 1996. Both representatives of the academic community and the judiciary took part in the debate. As a result, in May 2001, the UK decided to sign and ratify the Hague Convention of 1996.

The United Kingdom signed the Convention of 1996 on April 1, 2003, after it had been discussed in both Houses of Parliament. The text of the 1996 Hague Convention was published by the Foreign and Commonwealth Office as a regulatory document, together with additional explanatory memorandum, which was submitted to the Parliament on October 16, 2009.

In 2010, the United Kingdom Ministry of Justice issued a Memorandum, which contained explanations concerning the implementation of the Hague Convention of 1996 in the UK. The Memorandum submitted to the Parliament, along with the information concerning the Convention, contained a provision of the compatibility of the Hague Convention of 1996 with the European Convention for the Protection of Human Rights and Fundamental Freedoms of 1950.

The United Kingdom Ministry of Justice considers the Convention of 1996 as the EU Treaty in accordance with the European Communities Act of 1972.

The Explanatory Memorandum notes the close link of the Hague Convention of 1996 to the current EU law in the field of the children's rights protection. This refers, above all, to the Regulations "Brussels II".

The Convention of 1996 regulates relations between the United Kingdom and Denmark as EU Regulation does not apply to Denmark. The Hague Convention of 1996 also regulates relations between the UK and other countries that are not the EC members.

Under Art. 2 of the European Communities Act of 1972, the UK Ministry of Justice intends to take measures for the implementation of the Hague Convention of 1996 in England, Wales and Northern Ireland. In turn, the Ministry of Justice of Scotland intends to adopt specific regulations in order to implement the Hague Convention of 1996 in Scotland.

In 2011, in the lead-up to the ratification of the Hague Convention of 1996 by the United Kingdom, Scotland developed special regulations concerning the so-called "sheriff courts" (Act of Sederunt (Jurisdiction in Respect of Parental Responsibility and Measures for the Protection of Children Rules) of 2011. Retrieved from http://www.legislation.gov.uk/ssi/2011/192/body/made.). These regulations were drafted in terms of concepts such as "Contracting State", "foreign authorities," "foreign court" and refer directly to the Hague Convention of 1996.

The Hague Convention of 1996 came into force in the UK on November 1, 2012.

The United Kingdom Ministry of Justice submitted a number of reservations regarding certain provisions of the Hague Convention of 1996. Thus, in relation to Art. 34 of the Convention, the UK Government noted that requests under Art. 34, paragraph 1 of the Convention shall only be communicated to its authorities through the appropriate Central Authority; in relation to Art. 54, the UK Government made a reservation that it will not use the French language.

In accordance with Art. 29, para. 2 of the Hague Convention of 1996, allowing States "with more than one system of law, or States having autonomous territorial units, appoint more than one Central Authority", the United Kingdom government established autonomous Central Authorities in England, Wales, Scotland and Northern Ireland. In England, it is Lord Chancellor, who exercises the functions of the Central Authority being the head of the International Child Abduction and Contact Unit, in Wales these functions are exercised by a structural division of the Government of Wales; in Scotland - by a structural division of the Government of Scotland; in Northern Ireland - by Northern Ireland Court Service. It is noteworthy that the UK has also appointed a separate Central Authority in Gibraltar, whose functions are performed by the Justice Secretary.

Drafting a separate request form for the Convention, and a guidance for registration request to the Convention, 
which greatly simplifies the job of the Central Authorities of the Member States, may be considered as one of Great Britain's achievements in the process of implementation of the Hague Convention of 1996.

\section{Conclusion}

The experience of Germany, the UK and Finland in the field of implementation of the Hague Convention of 1996 may be useful for the Russian Federation in identifying the most effective ways of implementation of the Convention and establishing its own approach in this area. It seems that the experience of these countries may be of great value especially for strengthening national institutions and organs responsible for the implementation of the provisions of the 1996 Hague Convention, including enhancement of the operating potential of the Central Authority. This experience may be also used to develop a separate request form under the Hague Convention of 1996 and guidance on drafting such a request; to set up professional training programs of Russian judges, experts in the field of family law with the participation of representatives of the academic community; as well as to enhance public awareness of the Hague Convention of 1996 by placing appropriate information on the official website of the Central Authority, drafting brochures, organizing relevant presentations, conferences and seminars. Overall approach to addressing multiple challenges mentioned above must create a solid foundation for the integration of the Russian Federation into international legal system of the protection of children's rights, and will help to lift the protection of their rights and interests in the territory of the Russian Federation to a new level.

\section{Acknowledgments}

This article was prepared in frames of grant on methodological support of the application of the 1980 and 1996 Conventions in the Russian Federation awarded by the Ministry of Education of Russian Federation.

\section{References}

Abashidze, A., Gugunskiy, D., Koneva, A., Simonova, M., Solntsev, A. (2015). Current Problems of Interstate Cooperation of Russian Federation for the Protection of Children in Case of Disputes between Parents Living in Different States. Asian Social Science. Vol. 11, No. 14. 337-342.

Act of Sederunt (Jurisdiction in Respect of Parental Responsibility and Measures for the Protection of Children Rules) of 2011. Retrieved from http://www.legislation.gov.uk/ssi/2011/192/body/made.

Bosisio R.. (2012). Children's Right to Be Heard: What Children Think // The International Journal of Children's Rights, Volume 20, Issue 1. $141-154$.

Council Decision 2003/93/EC of 19 December 2002 authorizing the Member States, in the interest of the Community, to sign the 1996 Hague Convention on jurisdiction, applicable law, recognition, enforcement and cooperation in respect of parental responsibility and measures for the protection of children. Official Journal L 048. Retrieved from http://eur-lex.europa.eu/LexUriServ/Lex UriServ.do?uri=CELEX:32003D0093:en:HTML

Council Decision 2008/431/EC of 5 June 2008 authorizing certain Member States to ratify, or accede to, in the interest of the European Community, the 1996 Hague Convention on jurisdiction, applicable law, recognition, enforcement and cooperation in respect of parental responsibility and measures for the protection of children and authorizing certain Member States to make a declaration on the application of the relevant internal rules of the Community law. Official Journal $L 151$. Retrieved from http://eurlex.europa.eu/LexUriServ/LexUriServ.do?uri=OJ:L:2008:151:0036:0038:EN:PDF.

Council Regulation (EC) No 2201/2003 of 27 November 2003 concerning jurisdiction and the recognition and enforcement of judgments in matrimonial matters and the matters of parental responsibility, repealing Regulation (EC) No 1347/2000. Official Journal L 338 ,23/12/2003 P. 0001 - 0029. Retrieved from http://eur-lex.europa.eu/LexUriServ/LexUriServ.do?uri=CELEX:32003R2201:EN: HTML.

Federal'nyj zakon ot 27.07.2010 N 193-FZ (red. ot 23.07.2013) "Ob al'ternativnoj procedure uregulirovanija sporov s uchastiem posrednika (procedure mediacii)" [Federal law of the Russian Federation of 27 July 2010 No. 193-FZ "On the Alternative Dispute Resolution Procedure Involving Mediation (based on mediation procedure)" // Rossiyskaya gazeta - Russian Newspaper, 168.

Federal'nyy zakon Rossiyskoy Federacii ot 31 maya 2011 g. N 102-FZ "O prisoedinenii Rossiyskoy Federacii k Konvencii 0 grazhdansko-pravovyh aspektah mezhdunarodnogo pohischeniya detey" [Federal law as of 31 May 2011 No. 102-FZ "On the accession of the Russian Federation to the Hague Convention on the Civil Aspects of International Child Abduction"] /I Rossiyskaya gazeta - Russian Newspaper, 5495.

Federal'nyy zakon Rossiyskoy Federacii ot 5 maya 2014 g. N 126-FZ "O vnesenii izmeneniy v otdel'nye zakonodatel'nye akty Rossiyskoy Federacii v svyazi s prisoedineniem Rossiyskoy Federacii k Konvencii o grazhdansko-pravovyh aspektah mezhdunarodnogo pohischeniya detey" [Federal law as of 5 May 2014 No. 126-FZ "On amendments to some legislative acts of the Russian Federation in connection with the accession of the Russian Federation to the Hague Convention on the Civil Aspects 
of International Child Abduction Child Abduction"] // Rossiyskaya gazeta - Russian Newspaper, 101.

Hague Convention of 25 October 1980 on the Civil Aspects of International Child Abduction. Country Profile: Finland / drawn up by the Permanent Bureau. Hague Conference on Private International Law. Info. Doc. No 2. March 2011. Retrieved from http://www. hcch.net/upload/abduct2011cp_fi.pdf.

International Family Law Procedure Act in the version of the promulgation of 26 January 2005. Federal Law Gazette [Bundesgesetzblatt] part I, 162. Retrieved from http://www.gesetze-im-internet.de/englisch_intfamrvg/act_on_international_family_law.pdf.

Jones, Ph., Walker, G. (2011). Children's Rights in Practice. London: SAGE Publications Ltd.

Kabanov, V.L. (2014). Konvencija o grazhdansko-pravovyh aspektah mezhdunarodnogo pohishhenija detej kak komponent rossijskogo prava [the Convention on the Civil Aspects of International Child Abduction of 1980 as a component of Russian law]. Family and housing law - Semejnoe i zhilishhnoe pravo. N 1. 28-33.

Khazova, O.A. (2012). Prisoedinenie Rossii k Gaagskoj konvencii o grazhdansko-pravovyh aspektah mezhdunarodnogo pohishhenija detej i voprosy rossiijskogo semejnogo prava [Russia's accession to the Convention on the Civil Aspects of International Child Abduction of 1980 and the issues of the Russian family law]. Zakon - Law. N 5. 175-184.

Khazova,O.A., Sheljutto, M.L., Matveeva, M.V. (2013). Gaagskie konvencii o zashhite detej v Rossijskoj Federacii. Primenenie, ispolnenie, vozmozhnoe prisoedinenie [The Hague Conventions on Protection of Children in the Russian Federation. The application, performance, possible accession]. M.

Official web-page of Ministry of Foreign Affairs, Ministry of Justice, Ministry of Social Affairs and Health, Association for Abducted Children of Finland "International Child Abduction. Custody of Children. Recognition and enforcement of decisions on custody". Retrieved from http://oikeusministerio.fi/en/index/publications/esitteet/kansainvalinenlapsikaappaus/alkusanat.html.

Pardeck, J.T. (2006). Children's Rights: Policy and Practice. New York: Haworth Social Work Practice Press.

Responses of Germany to the Questionnaire concerning the practical operation of the Hague Convention of 25 October 1980 on the Civil Aspects of International Child Abduction and the Hague Convention of 19 October 1996 on Jurisdiction, Applicable Law, Recognition, Enforcement and Co-Operation in Respect of Parental Responsibility and Measures for the Protection of Children. Prel. Doc. No 1. 27 November 2010. Retrieved from http://www.hcch.net/index_en.php?act=publications.details\&pid=5291\& dtid $=33$.

Schepetkova, A.N. (2014). Porjadok osushhestvlenija Minobrnauki Rossii funkcij central'nogo organa Konvencii 1980 g. [The procedure of performing the functions of the Central Authority under the 1980 Convention by the Ministry of Education of the Russian Federation]. Family and housing law - Semejnoe i zhilishhnoe pravo. N 2. 12-17.

Sheljutto, M. L. (2014). Voprosy ratifikacii i implementacii Rossijskoj Federaciej Evropejskoj konvencii ob osushhestvlenii prav detej [Issues of ratification and implementation by the Russian Federation of the European Convention on the Exercise of Children's Rights]. Family and housing law - Semejnoe i zhilishhnoe pravo. N 1. 43-47.

Solntsev, A. M., \& Koneva, A.E. (2013). Mezhdunarodnye objazatel'stva rossijskoj federacii v sfere zashhity prav detej v svete dejatel'nosti mezhdunarodnyh universal'nyh i regional'nyh kontrol'nyh organov po pravam cheloveka [International obligations of the Russian Federation in the field of children's rights in the light of the activities of international global and regional monitoring bodies on human rights]. Evrazijskij juridicheskij zhurnal - Eurasian Law Journal. - M: Eurasian Research Institute of Law Sciences, No. 10. $38-42$ [in Russian].

Special Commission on the practical operation of the 1980 and 1996 Hague Conventions (1-10 June 2011). Conclusions and Recommendations. Retrieved from http://www.hcch.net/upload/concl28sc6_e.pdf.

Trigubovich, N.V. (2014). Nezakonnoe peremeshhenie ili uderzhanie rebenka soglasno Konvencii o grazhdansko-pravovyh aspektah mezhdunarodnogo pohishhenija detej $1980 \mathrm{~g}$. i rossijskomu zakonodatel'stvu [Unlawful abduction removal or retention of a child under the Convention on the Civil Aspects of International Child Abduction of 1980 and Russian legislation]. Family and housing law - Semejnoe i zhilishhnoe pravo. N 2. 6-11.

Ukaz Prezidenta RF ot 1 ijunja 2012 g. N 761 "O Nacional'noj strategii dejstvij v interesah detej na 2012 - 2017 gody" [Presidential Decree No. 761 of June 1, 2012 on the National Strategy of Action for Children for 2012-2017] // Collection of Laws of the Russian Federation - Sobranie zakonodatel'stva Rossijskoj Federacii, 23/2994.

Vigers, S. (2011). Mediating International Child Abduction Cases: The Hague Convention (Studies in Private International Law). Hart Publishing.

\section{Notes}

Note 1. Earlier Russia has adopted a plan of action for children for 1995-2000. 